\title{
Incidence of hypotension according to the discontinuation order of vasopressors: a matter of pharmacokinetics
}

\author{
Ross Freebairn ${ }^{1,2,3^{*}}$ (D) and Brigitte Hollander ${ }^{1}$ \\ See related research by Jeon et al., https://ccforum.biomedcentral.com/articles/10.1186/s13054-018-2034-9
}

We read with interest the study by Jeon and colleagues on hypotension developing during withdrawal of the two vasopressor agents, norepinephrine or vasopressin, demonstrating a higher incidence of hypotension at the end of the first hour with changes in norepinephrine than vasopressin [1].

The half-life of norepinephrine is reported as being between 2 and $6.8 \mathrm{~min}$ [2]. One hour is more than eight half-lives, and thus the norepinephrine would be very, very close to a new steady state of infusion. Even if the 6.8 min half-life is used this makes greater than $99.7 \%$ of the change having occurred. As the drop in norepinephrine infusion rate is $33.3 \%$ of the total, the new serum level would be approximately $67 \%$ of the original value.

In contrast, the half-life of vasopressin is $30 \mathrm{~min}$ [3]. One hour following the change two half-lives would have past, the vasopressin level would be still dropping, and only three quarters of the total change would have occurred. As the vasopressin infusion rates are altered only by $10 \%$, the new serum level of vasopressin would be $92.5 \%$ that of the original infusion.

Thus, the comparison is the effect of lowering one serum level of medications by $7.5 \%$ with lowering another serum level of medication by $33 \%$, a four-fold difference. It could be concluded that the higher incidence in hypotension with norepinephrine may be due to its more dramatic relative drop in serum level than in the vasopressin group.

Pharmacokinetics principles would suggest that hypotension due to vasopressin infusion changes would take longer to be clinically manifested than those of norepinephrine. Not only does the study compare different proportional changes, it measures the effect in a time frame too short to see the full effect of vasopressin infusion changes.
Acknowledgements

Not applicable.

Funding

None.

Availability of data and materials Not applicable.

Authors' contributions

$\mathrm{RF}$ and $\mathrm{BH}$ formulated the letter, researched the references, and read and approved the final manuscript.

Ethics approval and consent to participate

Not applicable.

Consent for publication

Not applicable.

Competing interests

The authors declare that they have no competing interests.

\section{Publisher's Note}

Springer Nature remains neutral with regard to jurisdictional claims in published maps and institutional affiliations.

\section{Author details \\ ${ }^{1}$ Hawke's Bay Hospital, Hastings, New Zealand. ${ }^{2}$ Chinese University of Hong Kong, Hong Kong, China. ${ }^{3}$ University of Otago, Dunedin, New Zealand.}

Received: 19 June 2018 Accepted: 19 July 2018

Published online: 12 March 2019

\section{References}

1. Jeon K, Song JU, Chung CR, Yang JH, Suh GY. Incidence of hypotension according to the discontinuation order of vasopressors in the management of septic shock: a prospective randomized trial (DOVSS). Crit Care. 2018; 22(1):131.

2. Beloeil H, Mazoit JX, Benhamou D, Duranteau J. Norepinephrine kinetics and dynamics in septic shock and trauma patients. Br J Anaesth. 2005;95(6):782-8

3. Solis-Herruzo JA, Gonzalez-Gamarra A, Castellano G, Muñoz-yagüe MT. Metabolic clearance rate of arginine vasopressin in patients with cirrhosis. Hepatology. 1992;16(4):974-9.

\footnotetext{
* Correspondence: ross.freebairn@xtra.co.nz

'Hawke's Bay Hospital, Hastings, New Zealand

${ }^{2}$ Chinese University of Hong Kong, Hong Kong, China

Full list of author information is available at the end of the article
}

(c) The Author(s). 2019 Open Access This article is distributed under the terms of the Creative Commons Attribution 4.0 International License (http://creativecommons.org/licenses/by/4.0/), which permits unrestricted use, distribution, and reproduction in any medium, provided you give appropriate credit to the original author(s) and the source, provide a link to the Creative Commons license, and indicate if changes were made. The Creative Commons Public Domain Dedication waiver (http://creativecommons.org/publicdomain/zero/1.0/) applies to the data made available in this article, unless otherwise stated. 